\title{
Historic human burials identified
}

Forensic tools help to name the occupants of four unmarked graves in Jamestown, Virginia.

Chris Cesare

28 July 2015

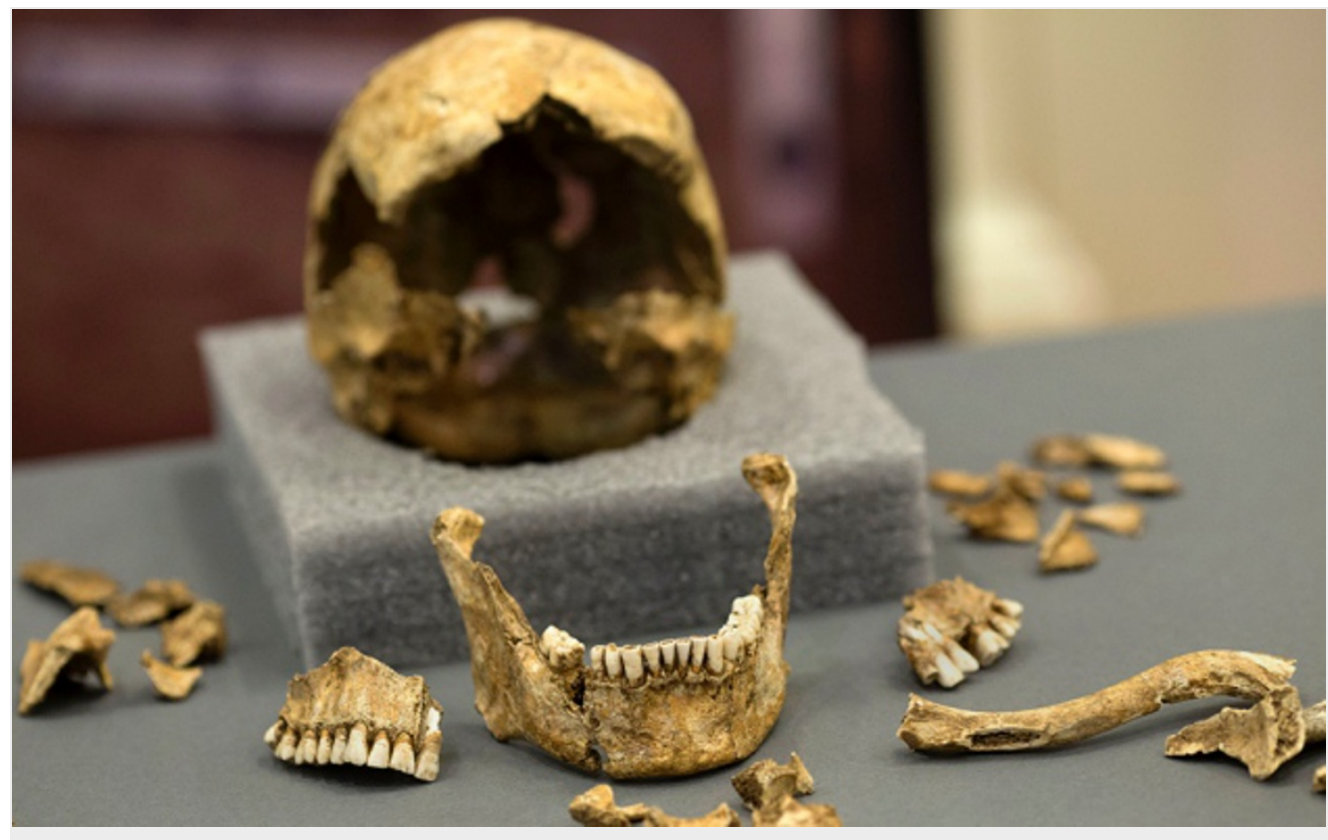

Chris Maddaloni/Nature

The remains of Captain Gabriel Archer and three other Jamestown settlers were excavated in 2013.

Skeletal remains buried beneath a historic church in Jamestown, Virginia, belonged to four prominent settlers of North America's first English colony.

The group included a minister, two military captains and the first English knight ever buried on the continent, a research team announced on 28 July at the Smithsonian Institute's National Museum of Natural History in Washington DC.

"These men witnessed the first three years of the establishment of the colony," said James Horn, the president of the Jamestown Rediscovery Foundation.

Smithsonian anthropologists teamed up with archaeologists at Jamestown Rediscovery to identify the four incomplete skeletons, which were excavated in 2013. First, the researchers narrowed down the potential candidates by analysing a handful of surviving documents from the colony's early years. Then they used 
chemical tests, genealogical records, digital analysis of bones and artefacts and contextual clues to make the final identifications.

One of the graves contained a simple shroud, but no coffin, and faced the church's congregation. These observations, along with an estimate of the man's age at death, allowed the team to identify the remains as the Reverend Robert Hunt, the first Anglican minister in Jamestown. Historical records indicate that he died in 1608 and was around 39 years old.

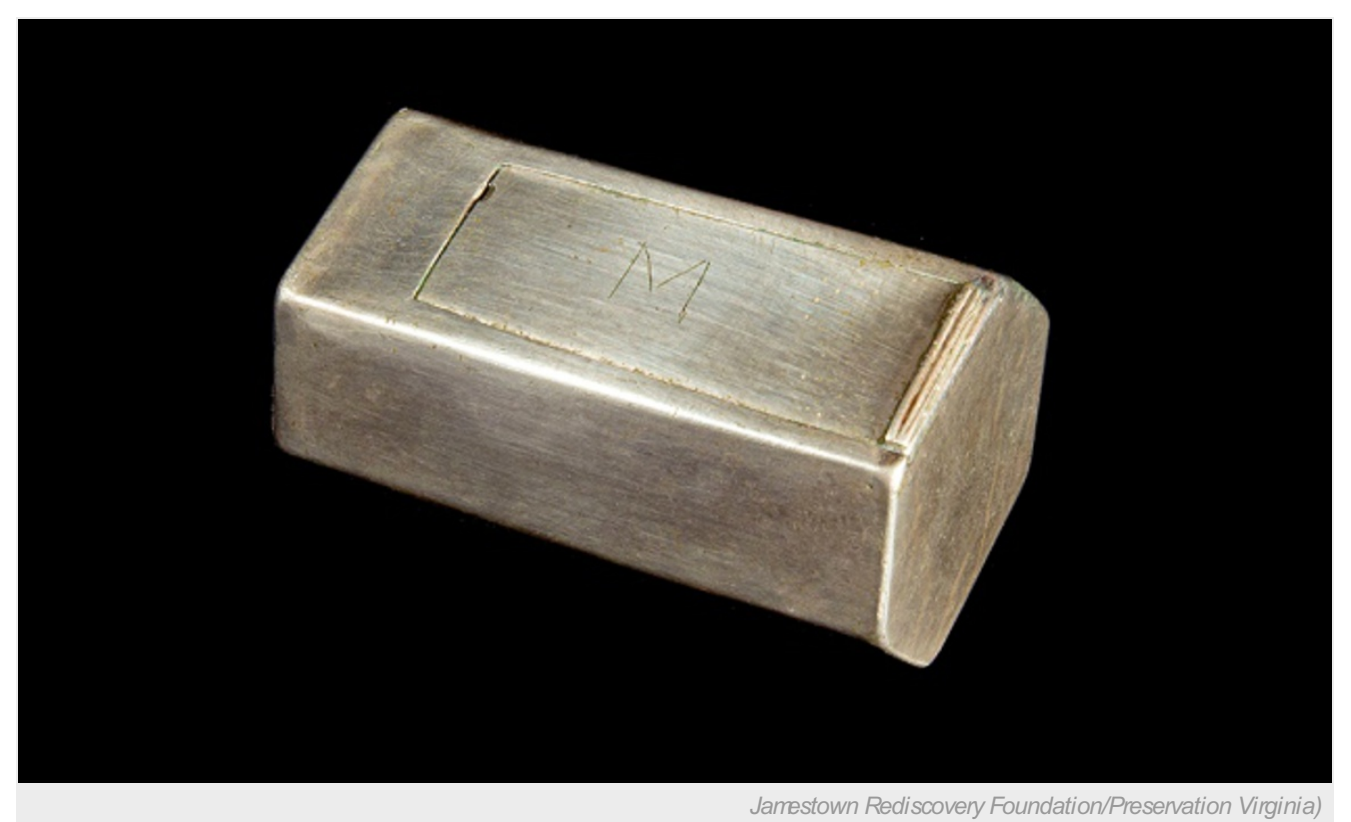

A silver reliquary found with the body of Captain Gabriel Archer may indicate that he was Catholic.

Similarly, researchers were able to link the second grave to Captain Gabriel Archer because it included a coffin and the decayed remnants of a ceremonial staff. Archer was also buried with a silvery reliquary that contained bones and a small vessel used for holy water. This discovery suggests that he was actually Catholic - even though he lived in a colony that tried to spread the Anglican faith to local tribes. "Was Archer a secret Catholic?" asked Horn. "Was this part of a secret Catholic cell? These are the questions we're going to continue to research." Archer died in late 1609 or 1610 during a dismal winter that claimed the lives of 250 settlers as a result of disease, starvation or attacks by Native Americans.

The presence of lead in another skeleton helped to confirm the identity of Captain William West. During life, the bones would have absorbed the heavy metal from pewter and glazed ceramic cups and bowls - items available only to people of means. A cloth sash in the burial indicated a military affiliation. Records show that he was killed during a battle with Native Americans in 1610.

The fourth skeleton exhibited even higher concentrations of lead and was identified as Sir Ferdinando Wainman, an English knight and a cousin of West's nephew. In a testament to his status, Wainman was buried in a human-shaped coffin with a square section for his head. Researchers reconstructed the design from the pattern of nails left behind in the grave after the wood deteriorated. Wainman also died in 1610.

Continued research on the site will use genetics to confirm the familial relationship between West and Wainman, Horn said, and archaeological and anthropological work will investigate the importance of religion in early Jamestown.

The Smithsonian plans to host a symposium to showcase the techniques that are used to make such discoveries. "This is a human story," said Douglas Owsley, the head of the physical-anthropology division at the institute's museum of natural history. "I think it is to our benefit to listen to what these bones can tell us about their lives."

Nature | doi:10.1038/nature.2015.18079

Nature ISSN0028-0836 ESSN 1476-4687

\section{SPRINGER NATURE}

